\title{
In the Eye of the Storm: the Italian Economy and the Eurozone Crisis
}

Martin J. Bull

The Eurozone crisis had a more significant and longer-lasting impact on Italy than on virtually any other Member State, with the effects still visible a decade after. The extent of the shock was surprising in view of progress Italy had apparently made in the 1990s in terms of enhancing its capacity to meet the demands of European Monetary Union. The explanation for this traumatic economic experience lies in Italy's deep, long-term, structural tensions which were placed under severe pressure during the 1990s and which were cracked open by the 2011 sovereign debt crisis. These have had long-standing economic effects as well as political ramifications in terms of a significant change in the Italy-EU relationship.

Keywords: Italian economy; Eurozone crisis; Europe; sovereign debt crisis; public debt; economic growth

If the Eurozone crisis was, on the one hand, a reflection of the inherent structural weaknesses in the Eurozone edifice (Turner 2011; Schelke 2011) and the inadequate response of the European elites to manage the crisis (Underhill 2011), it was, on the other hand, characterised by the public indebtedness of the 'old' Southern European countries (Italy, Portugal, Greece and Italy) - popularly perceived as Europe's 'flaky southern fringe' (Verney 2009, p. 1) and the collapse in confidence of the markets in their capacities to repay those debts (Bull 2012). Of these countries, Italy stood out in terms of both size, significance and impact. True, it could be argued that Greece was the immediate problem, facing a real (some would say inevitable) risk of default, and, in any case, the other southern European countries were in a 
similar predicament to that of Italy, facing low growth, high levels of public debt and downgrading of their credit ratings. Yet, while Ireland, Greece and Portugal were already, before 2011, receiving financial assistance from the EU, these economies were relatively small in the context of the Eurozone as a whole (Greece, for example, represented a mere 2.7 per cent of the total Eurozone's GDP). Italy's public debt, by comparison, amounted to approximately one third of all Eurozone debt. Its problem was that it was too large to be bailed out - at least in the terms in which Greece was being considered. It was not surprising, therefore, that the main concern of European and international political and economic elites was, from 2011 (if not earlier), that of contagion to Italy, as, for example, expressed by then Director of the European Central Bank, Jean Claude-Trichet, and Antonio Borges, responsible for the IMF's European Department (La Stampa, 20 September 2011 \& 24 September 2011).

The resulting crisis, the daily figures on the 'spread' (the difference in the ItalianGerman ten-year bond yield spread) and the eventual enforced resignation of Silvio Berlusconi as Prime Minster, placed Italy very much in the 'eye of the storm'. The impact, moreover, was long-term, with a near decade of recurrent crisis, EU-imposed austerity and slow recovery. That has also resulted in a significant non-economic consequence: a marked change in Italy's relationship with Europe, with Italian governments more hard-nosed about demands from the EU, and Italians more Eurosceptic than ever before. To simplify, 'Europe', as a consequence of the Eurozone crisis, is no longer widely seen as a model to which to aspire, but more of a burden: the vehicle of a German-inspired, inflexibly-imposed austerity and of a drop in Italians' standard of living. This is a long way from the heady days of the 1990s when Italy, against expectations, qualified for entry into the single currency and the country was widely seen as having been 'rescued' by Europe. The question, therefore, is: why was the impact of the Eurozone crisis on Italy so severe and long-lasting?; or, to what 
extent was the Eurozone crisis (alone) responsible for an economic 'lost decade', and are the Italians right to identify Europe as the main cause of their economic woes since $2008 ?$

This article attempts to answer these questions by first analysing the 'lost decade' that commenced in 2008 with the Eurozone crisis. It then, in the second section, contextualises the Eurozone crisis by outlining how the severity of the impact on Italy was, to a large extent, unexpected and unanticipated by both politicians and observers of the Italian political scene, and how this level of surprise inevitably placed focus on the Eurozone crisis as a highly 'disruptive' element in Italian economic development. The article then, through an analysis of Italy's economic performance prior to the Eurozone crisis and especially the fiscal crisis and loss of economic growth from the 1990s onwards, places the 'disruptive' element of the Eurozone crisis more clearly in historical context and helps explain why its impact was so severe in the Italian case.

\section{A Lost Decade? The Italian Economy During the Crisis (2008-17)}

For Italy, the crisis began in earnest in the second half of 2011 as contagion from the Greek economic crisis reached its shores, with a run on the Italian markets in August 2011, characterised by dramatic increases in the 'bond spread'. The European Central Bank (ECB) became involved in the Italian emergency budget and the identification of a set of structural and financial reforms (Italy had been 'policed', in the words on one politician). Italy's credit rating was downgraded by two of the main credit rating agencies, Standard \& Poor's (on 20 September from A+ to A) and Moody's (on 4 October from Aa2 to A2 with a negative outlook, this the first time it had downgraded Italy since May 1993), leaving Italy with the same credit rating as Malta, below countries such as Estonia and Slovenia, and above only Cyprus, Ireland, Portugal and Greece. The core of the Eurozone drama was subsequently played out during the following year and beyond (Jones 2012). The impact was severe not just in the short-term (Jones 2014) but also in terms of duration and recovery. Looking back 
over roughly a decade, the figures in Table 1 outline this picture, but the table should be supplemented with comparisons with the Euro-area countries, which confirm Italy's relative difficulties and failure to recover from the 2011 crisis. $^{1}$

If we start with growth, the figures reveal stagnation punctuated by four years (200809, 2012-13) of contraction. Italy's growth rates are almost the worst in the Eurozone, the main problem being a failure to recover after the 2011-12 recession. In the years 2013-16 only Greece and Finland had worse growth rates, and predictions for 2017 and 2018 will leave Italy in bottom place. The root of this problem appears to be in labour productivity which, relative to the Euro-area countries, plummeted after 2010 and then flat-lined, leaving only Greece below Italy from 2013 onwards. If we look more closely at Unit Labour Costs (the ratio of compensation to employee to labour productivity) Italy's, although falling (by the first quarter of 2017) by 9.2 per cent since reaching a peak in the fourth quarter of 2009 , have in fact become comparatively even higher than the Euro-average which has fallen by a steeper 13 per cent, leaving Unit Labour Costs in Italy 10.8 per cent higher than the Euroaverage in 2017. Noticeably, countries with higher Unit Labour Costs at the peak of the crisis (Greece, Spain, Ireland) have since fallen below those of Italy, and in 2017 only seven of the Euro-area countries (Cyprus, Estonia, Latvia, Lithuania, Luxembourg, Malta and Slovakia) have higher Unit Labour Costs than Italy. ${ }^{2}$

There is also a problem of internationalisation of the economy as reflected in export and Foreign Direct Investment (FDI) figures, and export figures. FDI inflows (as percentage of GDP) underwent a dramatic decline from 2.9 per cent in 2007 to -0.4 per cent in 2008 , with the figure only rising to 1.5 per cent by $2016 .^{3}$ A similar story pertains to FDI outflows which declined from 5.4 per cent in 2007 to 0.84 per cent in 2008 , with the 2016 figure (1.2 per cent) still considerably lower than that of $2007 .{ }^{4}$ However, this represents a relative improvement on the Euro-average figures, where FDI inflows declined from 9.9 per cent in 
2007 to 2.7 per cent in 2017 , and outflows from 11.5 per cent in 2007 to 3.8 per cent in 2016 . In the same period (2007-2016) that Italian exports as a percentage of GDP have increased by about 2.5 per cent (from 27.4 per cent to 29.9 percent), the Euro-average figures have increased by over 4.5 per cent (from 39.4 to 44.1 per cent), with Italy having been overtaken in this period by Spain and Greece, and left languishing in penultimate place (after France). ${ }^{5}$ There are of course differences in performance across different sectors, and the specialisedsupplier (industrial district) sector has performed better (where Italy remains one of the topranked exporters in textiles, clothing, leather goods and non-electronic machinery). However, the problem is one of scale, with a minority (about 20 per cent) of companies responsible for nearly all exports and producing 8 per cent of the national value-added (Bricco 2017, p. 2).

Unemployment soared in the period after 2008, peaking in 2014 at 12.7 per cent of the workforce. In 2009 there were nine countries in the Euro-area with higher unemployment rates than Italy, including Germany, France and Belgium. By 2016 this had shrunk to just two (Greece and Spain), and Italy has particular problems. The percentage of those out of employment for longer than 12 months (the long-term unemployment rate) has, since 2014, been higher than all other Euro-area countries except Greece and the Slovak Republic. Youth unemployment (15-24 year olds) peaked at 42.7 per cent in 2014, and since 2013 only Spain and Greece have had higher levels. There is also, in Italy, a specific problem of unemployment levels in the South which have been running at over 20 per cent (close to double those of the Centre and North of the country). For those in employment, average wages were still lower in 2016 than they were in 2008. For the entire decade, only Greece, Portugal, Slovenia, Estonia and the Slovak Republic have had lower average wages.

These difficulties are reflected in an almost consistent decline in tax revenue over the decade, especially after 2014, with only Slovenia, Portugal, Spain, Estonia and Greece having lower annual tax revenues from 2014 onwards. The difficulties are also reflected in a collapse 
in internal demand over the decade, while most other countries have witnessed a gradual increase. The forecast for 2017 leaves Italy with the lowest growth in demand in the Eurozone in 2017, with the economy becoming deflationary in 2016.

Table 1: Italian Economy 2008-16: Main Indicators

\begin{tabular}{|l|l|l|l|l|l|l|l|l|l|}
\hline & 2008 & 2009 & 2010 & 2011 & 2012 & 2013 & 2014 & 2015 & 2016 \\
\hline $\begin{array}{l}\text { Annual growth } \\
\text { (per cent GDP) }\end{array}$ & -1.1 & -5.5 & 1.6 & 0.7 & -2.9 & -1.7 & 0.2 & 0.6 & 0.8 \\
\hline $\begin{array}{l}\text { Public deficit } \\
\text { (per cent GDP) }\end{array}$ & -2.7 & -5.3 & -4.2 & -3.7 & -2.9 & -2.9 & -3.0 & -2.7 & -2.4 \\
\hline $\begin{array}{l}\text { Public debt } \\
\text { (per cent GDP) }\end{array}$ & 113 & 126 & 124.9 & 117.9 & 136.2 & 143.7 & 155.8 & 157.3 & + \\
\hline $\begin{array}{l}\text { Inflation } \\
\text { (annual growth } \\
\text { rate, per cent) }\end{array}$ & 3.3 & 0.8 & 1.5 & 2.8 & 3.0 & 1.2 & 0.2 & 0.0 & -0.1 \\
\hline $\begin{array}{l}\text { Tax revenue } \\
\text { (EUR capita) }\end{array}$ & $11.3 \mathrm{k}$ & $11.0 \mathrm{k}$ & $11.0 \mathrm{k}$ & $11.3 \mathrm{k}$ & $11.8 \mathrm{k}$ & $11.5 \mathrm{k}$ & $11.4 \mathrm{k}$ & $11.5 \mathrm{k}$ & + \\
\hline $\begin{array}{l}\text { Unemployment } \\
\text { (per cent } \\
\text { labour force) }\end{array}$ & 6.7 & 7.7 & 8.4 & 8.4 & 10.7 & 12.1 & 12.7 & 11.9 & 11.7 \\
\hline $\begin{array}{l}\text { Youth } \\
\text { unemployment } \\
\text { (per cent of } \\
\text { youth labour } \\
\text { force) }\end{array}$ & 21.2 & 25.3 & 27.9 & 29.1 & 35.3 & 40.0 & 42.7 & 40.3 & 37.8 \\
\hline $\begin{array}{l}\text { Productivity } \\
\text { (GDP per hour } \\
\text { worked) (2010 } \\
=100 \text { ) }\end{array}$ & 100 & 97.8 & 100.0 & 100.5 & 100.2 & 101.1 & 101.3 & 101.1 & 100.3 \\
\hline $\begin{array}{l}\text { Labour } \\
\text { productivity } \\
\text { (2010=1) }\end{array}$ & 1.0 & 0.9 & 1.0 & 1.0 & 0.9 & 0.9 & 0.9 & 0.9 & 0.9 \\
\hline $\begin{array}{l}\text { Internal } \\
\text { Demand } \\
\text { (annual growth } \\
\text { rate) }\end{array}$ & -1.2 & -4.2 & 1.9 & -0.5 & -5.7 & -2.7 & 0.3 & 1.0 & 0.9 \\
\hline $\begin{array}{l}\text { Average wages } \\
\text { (EUR)* }\end{array}$ & 26,644 & 25,158 & 26,456 & 25,004 & 26,608 & 25,298 & 25,418 & 30,726 & + \\
\hline $\begin{array}{l}\text { Long term } \\
\text { interest rates } \\
\text { (per cent per } \\
\text { annum) }\end{array}$ & 4.7 & 4.3 & 4.0 & 5.4 & 5.5 & 4.3 & 2.9 & 1.7 & 1.5 \\
\hline
\end{tabular}

* Original figures in USD, conversion to EUR based on yearly average exchange rates (https://www.ofx.com/en-gb/forex-news/historical-exchange-rates/yearly-average-rates/)

+ Figures not available

Source: OECD (2017) 
As a consequence, governments have struggled to keep the public deficit within the EU's three per cent rule, which was breached every year between 2009 and 2011. However, it has to be said that this was not out of keeping with the rest of the Euro-area, since only six countries between 2009 and 2016 managed to keep within this limit, and Italy's average for those years (3.3 per cent) was better than ten other countries. Indeed, despite the calamitous state of growth and productivity, there has been an effort to secure fiscal consolidation in the years since 2009. If one looks at the average primary balance 2009-16 excluding the public debt burden, Italy was second only to Germany in producing the highest primary surplus (1.2 per cent), and one of only six countries to produce an average surplus or neutral balance, a figure that improves even further if the structural balance is adjusted for the effects of the economic cycle by excluding interest as a percentage of potential GDP (Ministero dell'Economia e delle Finanze 2017). That achievement, however, did nothing to reduce the public debt, only slowed its previous rate of growth (between 2009 and 2016, it grew more slowly than seven other Euro-area countries). Italian public debt started the decade as the highest in the Euro area (save for Greece), and stayed that way throughout, except one year (2011) where its figure was higher even than Greece. By 2015 it had reached more than 150 per cent of GDP.

Finally, the result of years of ongoing sovereign debt crisis has contributed to reproducing a Eurozone banking crisis, but with Italy this time at the centre of it. This proved to be another surprise. Writing at the beginning of the Eurozone crisis, Quaglia (2009, pp. 1213) noted that 'Amongst the various European countries, Italy has not been hard hit by the financial turmoil: no Italian bank (or foreign bank operating in Italy) has failed, nor has it been rescued through direct public intervention. Moreover, with the exception of two Italian banks...no Italian bank has come under severe strain and the market's perception of their 
solvency has remained relatively good.' Nearly a decade later all that changed, as European stress tests in 2016 revealed the scale of the problems in the Italian banking system. Nearly a fifth of all Italian banking loans (to a value of 360 billion Euro) are classified as troubled (meaning unlikely ever to be repaid), and this equates to 40 per cent of all such bad loans in the Euro-area. If a systemic banking crisis were to unfold it could be beyond the reach of (and rules governing) a public bail out (Pavesi 2017). While it is clear that several of the banks got into a critical condition through poor lending and decision-making, the Governor of the Bank of Italy has argued that the primary cause is 'bad economic conditions, seven years of almost continuous recession ... Banking is a symptom, not the cause' (quoted in Goodman 2016). Be that as it may, the current banking crisis is at the same time threatening bank lending on which future economic growth depends. The banking crisis is, therefore, a slow-burning fuse that could, over time, dwarf all other economic issues.

\section{Contextualising the Eurozone Crisis}

Was it the Eurozone crisis that caused a change in the Italian economy's fortunes? Or were there are other factors at work which simply made the economy's handling of that crisis more difficult than in many other European countries? Much depends on the interpretation (and 'narrative') one adopts to understand the Eurozone crisis in all its considerable complexity. Jones $(2015,2016)$, for example, outlines three differing interpretations in the literature as to why some nations experienced a greater impact than others from the Eurozone crisis: 'financial', 'competitiveness' and 'indebtedness'. The 'financial' emphasises the 'disruptive' 'sudden stop' nature of the crisis as one primarily of contagion: capital liberalisation and an inflow of capital followed by a shock to the confidence of overseas investors in one country after another, who (rationally or irrationally) then liquidate their assets triggering a balance of payments crisis. The other two interpretations emphasise the performance of the national 
economies in the run up to the crisis - specifically in relation to their levels of public debt and their competitiveness/growth - as explanations. Adopting the specific perspective of the least number of anomalies and what should be the policy response to the crisis, Jones (2015) argues that a financial interpretation offers the best leverage. However, as he also argues, the explanations are not mutually exclusive: all the interpretations depend on the same three elements, they simply differ in their sequencing and correlations.

If we turn to the Italian case, then the question that arises is, given the long-term impact on the Italian economy of the Eurozone crisis, what was the state of the economy in the run-up to the crisis? Was the crisis largely inevitable and a consequence of the dire state of the economy, or was it an unanticipated 'disruptive' stop to an economy in a reasonable state of health? Di Quirico (2010, p. 16), for example, has argued that 'In Italy, the global crisis has impacted on a system that had deteriorated following twenty years of political instability and economic decline. So, it has only worsened conditions in a country already in crisis.' Yet, irrespective of the possible accuracy of such an assertion, it does not - in its broad two-decade sweep - account for the apparent achievements of Italian policy-makers in getting Italy into the Euro in the 1990s, the broader context of change this apparently represented and the expectations generated by these achievements. Indeed, returning to the literature of that period suggests that the largely popular interpretation of the Eurozone crisis (that it is chiefly responsible for Italy's woes) has some pedigree.

Between 1992 and 1998, five governments brought about a drastic change in the state of the government finances, resulting — against all expectations — in Italy qualifying for European Monetary Union (EMU) in the first wave of entrants in 1999. Instead of primary deficits there were substantial primary surpluses, the level of public debt began to decline after 1994, and the deficit declined from double-digit figures to be within the Maastricht's Treaty requirement of three per cent. This was achieved through a mix of expenditure cuts, 
tax increases and new taxes, combined with the commencement of structural reforms in pensions, welfare, labour relations and privatisation, as well as reforms to budgetary procedures which enhanced the role of the executive and Treasury (Radaelli 2001, pp. 28-9). Underpinning these changes was an apparent new elite consensus amongst a group of economists, technocrats and politicians, which had originated in negotiations over the Maastricht Treaty and was based on the idea that the increased demands of the 'European constraint' presented an opportunity to overcome the limitations of the old Italian political class in furthering the goals of sound public finance for long-term international gains (Dyson \& Featherstone 1996; Radaelli 1998). The Prime Ministers of the 1990s-Amato, Ciampi, Dini, Prodi and D'Alema — adhered to this new approach, two of these (Ciampi and Dini) running non-party technical governments, the former going on to become the Treasury Minister between 1996 and 1999 in the first governments of both Prodi and D’Alema. Italy was described as having been 'rescued by Europe' or 'condemned to success' (e.g. Ferrera \& Gualmini 2004; Di Palma et al. 2000) through the pressures exerted by Europe as a form of 'external constraint' (Dyson \& Featherstone 1996). Furthermore, looking forwards, observers tended to emphasise the continued, if not increased, presence of the 'external constraint' deriving from an independent European Central Bank in charge of monetary policy, the EU's Growth and Stability Pact and the role of EMU in providing financial stability (e.g. Radaelli 1990, p. 8; 2001, pp. 234-235). In the late 1990s, Mario Monti, the Italian European Commissioner (1995-2004, and responsible for the single market until 1999) referred to the consolidation of a 'culture of stability' (quoted in Di Palma 2000, p. 43) in Italy thanks to the Maastricht Treaty, a formidable achievement in view of the country's long-term reputation for instability. Moreover, at the first serious test of this apparent new-found capacity, the 2007-08 banking crisis, Italy's solidity seemed to be confirmed, since the country emerged relatively unscathed (Quaglia 2009, pp. 12-13). 
Yet, a mere three years later, when the banking crisis of 2008-09 gave way to a sovereign debt crisis in 2010-11 Italy's image shifted dramatically from solidity to being on the brink. In this line of thinking, the Eurozone crisis was a sudden 'disruptive' element in Italy's economic development. If so, then the questions are why the expectations of the 1990s were dashed and why many of the observers of that period got it so wrong? What happened to the so-called 'culture of stability'? To answer this question requires an assessment of the two key national interpretations of the Eurozone crisis in relation to Italy (public indebtedness and competitiveness/growth) prior to the crisis, especially unpicking developments in the 1990s and 2000s, and assessing what happened to the apparent economic achievements of the 1990s.

\section{The Long Roots of the Fiscal Crisis: Public Deficits and Public Debt}

For all the economic achievements of the 1990s, and the optimism generated by them, it should not be forgotten that they came, in fact, on the back of the biggest political and economic crisis in the Italian post-war period. The dramatic events of 1992-94 are, of course, remembered chiefly for the wave of corruption scandals. Yet, it should not be forgotten that this crisis was accompanied by economic turmoil in the form of a collapse in confidence of the markets and an alarming run on the currency that led to the lira being withdrawn from the Exchange Rate Mechanism (ERM) in September 1992. While, at the time, it looked as if this was a consequence of the political situation, in fact the economic crisis had much deeper roots of its own, bringing to an end an economic cycle that could be dated from Italy's entry into the ERM in 1978. This had been anticipated to correct the distortions in Italy's model of growth in the 1970s, based on public deficits, state subsidies to firms, repeated devaluations of the lira, high inflation and rising national debt. Yet, while a restructuring of industry did occur in the early 1980s and inflation was brought down, the ERM, as an 'external 
constraint', failed to enforce macro-economic discipline, largely because, in the period until the mid-1980s, it operated on a flexible basis, with frequent realignment of currencies in the system. Consequently, the distortions in the Italian political economy, especially regarding deficits and public debt, continued throughout the 1980s. Public debt as a percentage of GDP rose from 41.2 per cent 1970 to 59 per cent in 1980 and again to 97.8 per cent in 1990 , the latter rise being unprecedented in western democracies. By 1991 only Japan and United States had more outstanding debt than Italy in the world, and its ratio of outstanding debt to GDP was approximately twice the average of the other members of the European Union. Interest paid on the debt rose from 5.3 per cent in 1980 to 9.6 per cent in 1990 . This was not a problem to do with economic growth since, apart from one negative year (1975) and low figures in the recession of the early 1980s, economic growth was consistent and even punctuated by a so-called 'second economic miracle' in the 1980s. Rather, it was one of growth in public expenditure outstripping that of revenue. For example, while total revenue rose from 30 per cent of GDP in 1964 to 39 per cent in 1985, expenditure rose from 29 per cent to 51 per cent, thus preventing any reduction in the deficit (Franco \& Rizzo 2009, pp. 130-31).

The economic crisis of the early 1990s was hastened along by a tightening of the ERM. Currency realignments became less frequent in the late 1980s, and in 1990 the lira entered the 'narrow' band of the ERM, accompanied by the complete liberalisation of capital movements. It was followed by the decision to move towards EMU through the formulation of five convergence criteria in the Maastricht Treaty, the two most demanding for Italy of which were that budget deficits should be no more than three per cent of GDP (Italy's was in the region of 9 per cent) and that public debt should be no more than 60 per cent of GDP (Italy's was over 100 per cent). The drama of that crisis, and the resulting performance against the key Maastricht criteria, explain why few observers or participants expected Italy 
to qualify in the first wave of entrants for EMU. Prime Minister Lamberto Dini (1995-1996) attempted to postpone the Maastricht timetable because he feared that the adjustment could not be achieved in time, and the European Commission's first formal assessment (1997) of the likely first entrants noted that Italy was still adrift. This raises the question of the exact nature of the achievement of meeting Maastricht (and the optimism it generated amongst politicians and observers) and how lasting it was ever likely to be. It could be argued that it was based on two assumptions (one economic and the other political) whose veracity had yet to be tested: first, that it demonstrated Italy's economic ability to achieve fiscal sustainability (as opposed to temporary fiscal consolidation); and second, that it reflected the replacement of the old Christian Democratic 'regime' with a new elite who had brought to budgetary policy-making a new long-term 'culture of stability'. Both these assumptions proved to be more apparent than real.

On the economic front, while the Italian government achieved the necessary fiscal adjustment to enter the single currency, it did not guarantee that it would maintain this into the future. In fact, much depended on the nature of the adjustment undertaken in the pre-entry phase. How a nation-state consolidated its finances to meet the Maastricht criteria would have an inevitable impact on future sustainability, since 'budget consolidations relying too heavily on the revenue side by raising taxes rather than on the expenditure side by cutting spending are less likely to be successful and sustainable' (Blavoukos \& Pagoulatos 2008, p. 234). Successful consolidations favour a reduction in government spending over increasing government revenues, reductions in current government spending over public investment spending, and tackling politically sensitive issues such as public expenditure on subsidies, transfers and wages. 'As a result, successful consolidations are characterised by continued improvements in the budget balance following the conclusion of the consolidation phase' (ibid., 234). Significantly, it was possible to achieve fiscal consolidation and meet the 
Maastricht criteria through macro-economic changes which did not necessarily touch on deeper structural reforms that would be necessary to sustainability over the longer-term. Moreover, the Maastricht criteria, although rigid in and of themselves, were not prescriptive in terms of how member states should meet those criteria, if anything giving 'more emphasis to fiscal consolidation rather than fiscal sustainability', thus largely overlooking the quality of fiscal adjustment and therefore fiscal sustainability in the new currency (Blavoukos \& Pagoulatos 2008, pp. 233-234; Dyson 2006, p. 11). Perhaps inevitably, in view of the short time period between the signing of the Treaty and its deadline, a large non-structural component would be expected, and in fact, the one criterion which had the strongest implications for sustainability — reducing the public sector debt to 60 per cent of GDP — was, in the run-up to the deadline, relaxed to a requirement of evidence of a steady decrease in the public debt. The Italian consolidation in the pre-entry phase was achieved primarily through raising tax revenue (including a special Euro-tax) and capital spending reductions, but with little reduction in government primary expenditure and only limited structural reforms (which were started, for example in pensions, but remained either impartial or incomplete) (Bardone and Reitano 2009). Once the currency was launched, moreover, the EU relaxed its own rules. Fiscal consolidation and sustainability were meant to be enforced through the Stability and Growth Pact's Excessive Debt Procedure for those countries in breach of the three per cent rule, yet a more flexible stance was adopted in 2002 in the face of the French and German economies struggling to meet the rule. This undermined the SGP's credibility and reduced the pressure on countries (especially the Southern European states) to continue with fiscal consolidation.

On the political front, once Maastricht was achieved, the new consensus or 'culture of stability' began to evaporate, if indeed such a culture ever really existed. While there is little doubt that a new approach was adopted amongst the Italian team negotiating the Maastricht 
Treaty which carried over into Italian domestic politics as a result of the vacuum created by the 1992-93 crisis, at the same time, the views of a number of other politicians and parties were always more ambivalent: accepting that failing to enter the single currency would be unthinkable in a country so pro-European, but, on the other hand, recognising that the macroeconomic changes necessary to meet Maastricht would require unpopular tax rises and cuts in expenditure. However, several parties voted against the Maastricht Treaty in Parliament, two of which (Communist Refoundation and a reconstructed Italian Social Movement named National Alliance) would serve in future governing coalitions, and several politicians voting for the Treaty at the same time made clear their views that the convergence criteria should be subject to some flexibility (Gualdesi 1994, pp. 42-47). This was particularly noteworthy with respect to politicians of Forza Italia, the most significant of the new political parties to emerge in the 1990s (Dastoli 1996, pp. 172-173). Finally, if the political composition of the new consensus was oriented towards the new centre-left which (save for eight months) governed Italy between June 1992 and June 2001 (Di Quirico 2003, pp. 16-17), it was followed by five years (2001-06) of the more Eurosceptical centre-right under Berlusconi.

It was, therefore, perhaps not surprising that in the early 2000s Italy came close to breaching the three per cent rule (requiring one-off corrective measures), that public debt as a percentage of GDP remained largely unchanged and that the drive behind structural reforms, essential to the transition from fiscal consolidation to fiscal sustainability (pensions, labour market, welfare, privatisation) faltered. Annual budgets no longer prioritised reducing the deficit, which began to widen in the first half of the 2000s, as a consequence of only modest growth in GDP (partly suppressed by the dependence on tax increases and capital-spending reductions to enter the Euro). Furthermore, without the more structural measures being progressively implemented to replace the temporary measures of the mid-late 1990s, Italian governments - faced with unexpected low growth - reverted to further temporary measures 
from 2001 onwards (e.g. sales of real estate, tax amnesties, new legislation to generate future tax revenue).

The impact of this deterioration on the levels of public debt was apparent. While there was, on the face of it, an impressive reduction in the level of public debt (about 14 per cent) in the decade before the beginning of the 2008 world recession (1997-2007), most of this was, in fact, accounted for by temporary, extraordinary measures (Franco \& Rizza 2009, p. 136), and, with primary current expenditure rising faster than GDP in the first half of the 2000s, the primary balance shrank from 6.6 per cent of GDP in 1997 to almost zero in 2005, with the consequences that the ratio of debt to GDP began rising again in 2005 to 105.8 per cent. In that year, the European Council alerted Italy to its excessive deficit and made it subject to the procedure, giving it until 2007 to address the situation.

This is not to suggest that Italy's fiscal situation was a direct cause of the crisis. Italy's long-term public debt was always manageable, not only because the Italian government had become accustomed to doing so, but also because of who owned it. In contrast with its southern European neighbours, such as Greece and Portugal, as well as Ireland, Italy was not indebted primarily to foreign central and other banks (and especially to the EU's core countries). Italy's debt was primarily domestically owned: 'it has a relative conservative banking sector, a large stockpile of domestic savings, and even larger stockpile of household wealth' (Jones 2012, p. 87). Consequently, when the banking crisis began in 2008 and overseas money was withdrawn from those countries highly dependent upon it, they entered into crisis while Italy could continue to manage its indebtedness and in the short-term retained the confidence of overseas investors. Nevertheless, the sheer size of the Italian public debt burden - and the evidence that Italy was, especially with the interest paid on the deb, struggling to move from fiscal consolidation to fiscal sustainability-exposed the country to the risk of contagion; and this occurred when banks, facing substantial losses on 
their loans to Greece and other countries, lost confidence in Italy's ability to re-pay its debt and therefore in investing in Italy's sovereign debt refinancing (Jones 2012, pp. 88-89). The resulting crisis revealed 'a potentially lethal connection between weak banks invested in risky sovereign debt and governments too indebted to prop up the banks' (Barber 2017).

\section{The Long-Term Loss of Growth}

The figures for economic growth and productivity in the 2008-17 decade make miserable reading. However, they have to be placed in a longer context, for over a period of fifteen years, the Italian economy had been losing its 'social capacity for growth' (Toniolo 2013, p. 28). Long before the Eurozone crisis there was an extended debate about the so-called 'decline' of the Italian economy (e.g. Nardozzi 2004; Toniolo \& Visco 2004; Saltari \& Travaglini 2006), the roots of which were commonly located in a transformation of the world economy in ways that constituted serious challenges to Italy's postwar economic growth model (Battilani \& Fauri 2014, ch. 5).

First, there was the rapid diffusion of new technologies in the early 1990s following the end of the Cold War. Italy failed to exploit this so-called 'new economy' to the degree of other countries (in terms of adoption of new technologies in existing firms to boost productivity, and the creation of new firms based on those new technologies) both because of the prevalence of small and medium enterprises using more traditional methods of production and the archaic nature of Italy's state regulation, where there have been significant barriers to product innovation, labour market rigidities, low investment in research and infrastructure and inadequacies in the educational system (Trento 2003, pp. 1088-1091).

Second, a broader process of globalisation of the world economy in finance, technology and services began, with the breaking down of trade barriers. Since then, competition between national economies has been increasingly determined by their levels of 
international integration in terms of the capacity of national firms to establish a presence in international markets as well as the attractiveness of a country to multinational presence, as reflected in import/export levels and (incoming and outgoing) foreign direct investment (FDI), which are also an essential means of diffusing new technologies. This has constituted a challenge to Italy which has always attracted low levels of FDI because of the low innovative capacity of existing firms and the costs of setting up and doing business there, thus suppressing further the already weak capacities of Italian firms to increase their FDI abroad, many of which have tended to prioritise domestic investment (especially in the South). Under the full force of competition and the ending of state support and favourable funding rates, large firms in Italy began to find themselves in difficulties in the 1990s. The state sector of the economy began to undergo partial privatisation while large private firms, accustomed to state support and protective practices, found their competitive edge dented by changes in corporate governance and the globalisation of industrial and financial markets. By the turn of the Millennium there were questions being asked about the long-term viability of large industry in Italy (e.g. Trento 2012; Berta 2016). There was a consistent decline in the average size of Italian firms (as measured in number of workers) which, by 2008, had shrunk to only half the average of the five main EU countries, entailing a reduction in research and development during a period when the adoption of new technology was needed (Toniolo 2013, pp. 29-30).

Third, there began a geo-economic reshaping of the world economy with the emergence of countries competing directly with the old economies of Europe. This included central and eastern European countries which joined the European Union in 2004 and, more importantly for Italy, the rise of the Asian economies which witnessed a shift in world trade away from Europe and the emergence of new economic powerhouses. In particular, the rapid economic growth of China posed a significant challenge to Italy because it struck at the heart 
of those 'Made in Italy' goods in which Italian small and medium sized enterprises had become market leaders in previous decades (Onida 2004).

These factors were already having a suppressing effect on Italy's economic growth long before the launch of the single currency (indeed, despite the lira depreciating by roughly 30 per cent between 1992 and 1995, economic performance in the 1990s was the worst of any decade previously since the war), one of the main effects of which was, for Italy, a loss of competitiveness. While there are different measures of competitiveness and while global figures overlook the performance of individual sectors (see, for example, Tiffin 2014), it is generally accepted that high inflation and the strengthening of the Euro, which could not be counter-balanced through a devaluation of the currency, led to a worsening of Italy's current accounts. At the same time, the European Central Bank's setting of a single nominal interest rate for all of the Euro-area had the effect of bringing down real (i.e. accounting for inflation) interest rates: in the decade 1999-2008, average long-term interest rates in Italy were 2.2 per cent compared with 6.2 per cent for the previous decade. This meant that, despite the loss of competitiveness, growth could be maintained through easier credit (enhanced by the liberalisation of banking regulations in the single market) and more manageable deficits. As a result, the loss of competitiveness did not lead to a reduction in wage rates and more flexible labour markets in order to maintain growth and employment rates (Le Cacheux 2010, pp. 5051). And this masked several economic weaknesses (low productivity, high labour costs and other structural problems) as well as obviating the need to do something about them. The competitiveness of Italian goods fell by 20 per cent between 1995 and 2002, Italy dropping below China and Canada to sixth place in the list of the world's biggest exporters (Trento 2003, p. 1093). Average growth between 1990 and 2001 was 1.7 per cent which was almost half that of the previous decade, and below the European average. Industrial productivity 
increased by an average of only 1.4 per cent over the same period, against 2.6 per cent for the 1980s.

Italy was not unique in this sense. On the contrary, it could be argued that the Euro encouraged the expansion of the southern European economies, but the financial markets did not function effectively to impose 'discipline' on them in terms of enforcing structural reforms in the labour market and elsewhere (Tombazos 2011, p. 34). At the same time, the Euro exacerbated severe demand imbalances through German banks lending to the southern European states, thus creating demand for German exports, exporting credit dependence and increasing the gap between southern European deficits and German surpluses (Bagnai 2014, ch. 2; Featherstone 2011, p. 200). Yet, for all that, the Italian economy remained characterised by continued sluggish growth. While average growth rates for the decade after the launch of the Euro (1999-2008) were strong in Greece (4.15 per cent) and Spain (3.54 per cnet)—with the Spanish case also marked by a housing bubble-Italy averaged 1.36 per cent, well below the average growth rate of 2.12 per cent for the Euro area overall.

As with public indebtedness, the long-term loss of competitiveness and decline in economic growth were not direct causes of the Eurozone crisis insofar as 'countries did not get into crisis because they lost competitiveness. They may have lost competitiveness and fallen into crisis, but the two developments are not causally connected' (Jones 2016, p. 80). Yet, there is no doubt that the pre-existing state of its competitiveness has made it more difficult to recover from that crisis. With historic drops in manufacturing employment, productivity, exports and world export market share, the Italian economy is no easy position to recover, especially when it is, at the same time, hampered by a significant public debt and a banking system made fragile by a large percentage of non-performing loans.

\section{Conclusion: Economic Impact, Political Ramifications}


For the Italian economy, the 2008-17 decade was almost entirely contextualised by the Eurozone crisis. At peak of the crisis (2011-12), moreover, the Italian economy was in the eye of the storm: in a less critical condition than Greece but much more significant to the Eurozone and its future. The intensity of the impact and Italy's pivotal role in the crisis was not anticipated. The crisis for Italy was primarily caused by contagion, it was largely financial in nature (a collapse in confidence of investors) with its dynamics beyond national control. At the same time, and essentially for the same reasoning, the crisis did not change the essential trajectory of the Italian economy but rather exacerbated existing trends, making it more difficult for the economy to recover; indeed, it is fair to say that 15 years of poor performance left the economy unable to withstand the impact of a crisis of such magnitude. It follows, therefore, that to understand the Italian economy today, one needs to go back beyond 2008 to the early 1990s. Indeed, it is probably more accurate to identify the 1990s as a watershed decade which was as - if not more-important than the decade ushered in by the world economic crisis of 2008, dramatic as the latter was. Ironically, in the 1990s, precisely in a period when observers and Italian politicians viewed a fundamental change taking place amongst the Italian political class in its approach to the public finances, the motors of longterm economic growth were faltering. This was a result of transformations taking place in the world economy combined with Italy's entry into the single currency, all of which were challenging the long-standing tenets of the Italian postwar model of growth. The entry into the single currency in particular changed the macro-economic regulatory framework within which Italy had long operated, replacing the constraint of the market with an institutional constraint in the form of the financial rules set by the EU. For an economy based on a model of growth based on deficit budgeting, high public debt and depreciations of the currency, adjusting to this new framework proved a serious challenge. 
Recovery from the Eurozone crisis has, therefore, been a long and slow process, and Italy remains a country which continues to worry the EU—as well as Deutsch Bank (Martin 2017) — because of its size and significance to the Eurozone. The European Commission, in November 2016, adopted the 'Alert Mechanism Report', identifying Italy as one of the Member States needing in-depth review. In its subsequent report of 22 May 2017 it concluded that 'Italy is experiencing excessive macroeconomic imbalances. High government debt and protracted weak productivity dynamics imply risks with cross-border relevance, in a context of non-performing loans and unemployment. The need for action to reduce the risk of adverse effects on the Italian economy and, given its size and cross-border relevance, on the economic and monetary union, is particularly important' (European Commission 2017, p. 3). The recommendations essentially follow the pattern of old: greater fiscal discipline, reforms to encourage growth and structural reforms to improve productivity.

Finally, the effects of the Eurozone crisis have not been just economic but political too. Indeed, the political ramifications are likely to be of greater duration, specifically in relation to Italy's longstanding relationship to Europe, which has undergone fundamental change in two significant respects. First, while the EU's policing of the Italian government's management of the economy no longer comes as a shock - as it did in the early period of the crisis - its nature is no longer regarded as in the past as inherently benign. In 2012, of course, the Italian government accepted the EU's Fiscal Compact (officially known as the Treaty on Stability, Coordination and Governance) which circumscribes national budgetary sovereignty and, in the Italian case, means shaving off approximately two per cent of GDP annually for years to come. Yet, research has shown that the motivation for this acceptance on the part of the Italian government was not driven by conventional notions of the value of the EU as an 'external constraint' (which had shaped the consensus until the 1990s), but rather by simple fears of market punishment (Moschella 2017). That has tended to be confirmed by the 
approach of Italian governments since the crisis, where we have witnessed an increasing tendency to contest EU proposals on fiscal consolidation and, in negotiations, to argue for greater recognition of cyclical conditions. This became a hallmark, for example, of the Renzi government of 2014-16, an approach which paved the way for allowances in the 2017 Stability Programme for the impact of the migrant crisis in southern Italy and the earthquake in the central regions. The EU is seen as having been superseded in its role as a benign 'external constraint.' Indeed, it could be argued that Renzi views the situation as having been reversed, with Italian politics now acting as an active and legitimate 'constraint' on the EU (Jones 2017, p. 61). The Italy-EU relationship has become more testy, with governments challenging not just the specifics of EU budgetary requirements but also the broader policy of austerity.

Second, Italians have become more Eurosceptic than ever before. Europe is no longer seen as a model of good governance to which to aspire and Italy is no longer viewed as being 'rescued' by Europe. Europe's austerity policy is viewed by a majority of Italians as not working, and they also feel that the policy is in the interests of just a few countries despite the existence of realistic alternatives (Andretta 2018). Trust in the EU amongst Italians suffered a decline from 56.8 per cent in 2007 to a low point of 27 per cent in 2013 (recovering to 33.7 per cent in 2016). Satisfaction in EU democracy underwent a similar decline from 55.8 per cent in 2007 to a low point of 33.7 per cent in 2014 (recovering to 47.2 per cent in 2016). The customary wide gap between Italians' very poor satisfaction with their own democracy and that of EU democracy shrank during the crisis. The Euro, moreover, has become the particular focus of Italian anger, viewed as responsible for the austerity that was imposed on Italy following the Eurozone crisis. Support for the Euro amongst Italians declined from 72.9 per cent in 2007 to 59.2 per cent in 2016 (Batsaikhan \& Darvas 2017). Consequently, a debate on leaving the Euro gathered pace in 2017, with two parties (the Five Star Movement 
and the Northern League) proposing abandoning the single currency and Berlusconi's Forza Italia the adoption of a parallel currency (Politi 2017). In short, only 20 years after Romano Prodi passed his Euro super tax to qualify for the Euro and less than ten years since Berlusconi's steep increases in taxation to keep the country in it, Italy was headed for its 2018 national elections with only one mainstream party (the Democratic Party, PD) in favour of staying in the single currency. The political ramifications from the Eurozone crisis could yet produce another watershed moment in Italy's long-term political and economic development.

The author thanks Erik Jones as well as the anonymous referees for their comments and suggestions on an earlier draft of this article. The usual disclaimer applies.

\section{References}

Andretta, M. (2018) 'Protest in Italy in times of crisis: a cross-government comparison' South European Society and Politics, vol. 23, no. 1, pp. [to add]

Bagnai, A. (2014) L'Italia può farcela. Equità, flessibilità, democrazia. Strategie pe vivere nella globalizzazione, Il Saggiatore, Milano.

Barber, T. (2016) 'The “doom loop” that ties Italian banks', Financial Times, 7 March.

Bardone, L. \& Reitano, V. E. (2009) 'Italy in the Euro area: the adjustment challenge', in Italy in the EMU: The Challenges of Adjustment and Growth, ed. M. Buti, Palgrave, Basingstoke, pp. 
Batsaikhan, U. \& Darvas, Z. (2017) 'European Spring-trust in the EU and democracy is recovering'， http://bruegel.org/2017/03/european-spring-trust-in-the-eu-and-democracy-isrecovering/ (accessed 27 September 2017).

Battilani, P. \& Fauri, F. (2014) L'economia italiana italiana dal 1945 a oggi, Bologna, Il Mulino.

Berta, G. (2016) Che fine ha fatto il capitalismo italiano?, Il Mulino, Bologna.

Blavoukos, S. \& Pagoulatos, G. (2008) 'The limits of EMU conditionality: fiscal adjustment in southern europe', Journal of Public Policy, vol. 28, no. 2, pp. 229-253.

Bricco, P. (2017) 'Ten years later the world is back in business, but Italy is still struggling', ItalyEurope24, 13 January 2017.

Bull, M. J. (2012) 'Southern Europe and the “trade off': architects of European disunion?', in European Disunion: Between Sovereignty and Solidarity, eds. J. Hayward \& R. Wurzel, Palgrave Macmillan, London, pp. 283-297.

Dastoli, P. V. (1996) 'The stone guest: Italy on the threshold of European Monetary Union', in Italian Politics: the Stalled Transition, eds M. Caciagli \& D. Kertzer, Westview Press, Boulder, pp. 169-185.

Di Quirico, R. (2003) 'Italy, Europe and the European presidency of 2003', No. 27 (July), Research and European Issues, Groupement D'Études et de Recherches, Notre Europe, https://infoeuropa.eurocid.pt/files/database/000015001-000020000/000019866.pdf, pp. 1-53 (accessed 17 May 2017).

Di Quirico, R. (2010) 'Italy and the global economic crisis', Bulletin of Italian Politics, vol. 2, no. 2 , pp. 3-19. 
Dyson, K. (2006) 'Euro entry as defining and negotiating fit: conditionality, contagion and domestic politics', in Enlarging the Euro Area. External Empowerment and Domestic Transformation in East Central Europe, ed K. Dyson, Oxford University Press, Oxford, pp. $7-43$.

Dyson, K. \& Featherstone, K. (1996) 'Italy and EMU as a "vincolo esterno”: empowering the technocrats, transforming the State', Southern European Society and Politics, vol. 1, no. 2, pp. 272-299.

European Commission (2017) 'Recommendation for a Council recommendation on the 2017 National Reform Programme of Italy and delivering a Council opinion on the 2017 stability programme of Italy', Brussels, 22.5 COM(2017) 511 final.

Featherstone, K. (2011) 'The Greek sovereign debt crisis and EMU: A failing state in a skewed regime', Journal of Common Market Studies, vol. 49, no. 2, pp. 193-217.

Franco, D. \& Rizza, P. (2009), 'Ensuring a sustainable fiscal consolidation', in Italy in EMU. The Challenges of Adjustment and Growth, eds M. Buti, Macmillan, London, pp. 129-172.

Goodman, P. (2017) 'Italian banks are in a slow motion crisis. And Europe may pay', New York Times, 19 November 2016.

https://www.nytimes.com/2016/11/20/business/dealbook/italys-banks-are-in-a-slow-motioncrisis-and-europe-may-pay.html (accessed 15 May 2017)

Gualdesi, M. N. (1994) 'L'Italia e l'integrazione europea', in L'Italia nella Politica Internazionale, Anno Ventunesimo, Edizione 1994, ed Istituto Affari Internazionali, Editore SIPI, Roma, pp. 38-60.

Jones, E. (2012) 'Italy’s sovereign debt crisis', Survival, vol. 54, no. 1, pp. 83-110. 
Jones, E. (2014) The Year the European Crisis Ended, Palgrave, London.

Jones, E. (2015) 'Getting the story right: how you should choose between different interpretations of the European crisis (and why you should care)', Journal of European Integration, vol. 37, no. 7, pp., 817-832, DOI: 10.1080/07036337.2015.1079376

Jones, E. (2016) 'Competitiveness and the European financial crisis', in The Political and Economic Dynamics of the Eurozone Crisis, ed J. A. Caporaso \& M. Rhodes, Oxford University Press, Oxford, pp. 79-99.

Jones, E. (2017) 'I rapporti con 1'Europa: oltre il "vincolo esterno"?, in Politica in Italia. I fatti dell'anno e le interpretazioni, eds A. Chiaramonte \& A. Wilson, Il Mulino, Bologna, pp. 61-79.

Le Cacheux, J. (2010) 'How to herd cats: economic policy coordination in the euro zone in tough times', Journal of European Integration, vol. 32, no. 1, pp. 41-58.

OECD (2017) Various Statistics, doi: 10.1787/1f84150b-en (Accessed on 25 May 2017)

Martin, W. (2017) 'Deutsche Bank: Italy's 3 big problems could trigger the next financial crisis - and bring the euro down with it', Business Insider, http://uk.businessinsider.com/italy-financial-crisis-deutsche-bank-2017-9 $\quad$ (accessed 22 October 2017).

Ministero dell'Economia e delle Finanze (2017) 'Fiscal consolidation while promoting growth. A comparison between Eurozone countries (2009-2016)', Appendix to Letter from Pier Carlo Padoan (Italian Minister of Economy) to Valdis Dombrovskis (Vice-President, European Commission) and Pierre Moscovici (Commissioner, European Commission), 20 May. 
Moschella, M. (2017) 'Italy and the fiscal compact: Why does a country commit to permanent austerity?', Italian Political Science Review, vol. 47, no. 2, pp. 205-225.

Nardozzi, G. (2004) Miracolo e declino. L'Italia fra concorrenza e protezione, Laterza, Bari.

Onida, F. (2004) Se il piccolo non cresce: Piccole e medie imprese italiane in affanno, Il Mulino, Bologna.

Pavesi, F. (2017), 'Ecco le 114 banche italiane a rischio per le sofferenze', Il Sole 24 Ore, 25 March: $\quad$ http://www.ilsole24ore.com/art/finanza-e-mercati/2017-03-24/quelle-114-bancheche-hanno-sofferenze-e-incagli-che-superano-capitale--

201607.shtml?uuid=AE6qY5s\&refresh_ce=1 (accessed 17 May 2017).

Politi, J. (2017) 'Italian debate on merits of ditching Euro grows louder', 16 March: https://www.ft.com/content/6d67cf26-08b2-11e7-97d1-5e720a26771b (accessed 17 March 2017).

Quaglia, L. (2009) 'The response to the global financial turmoil in Italy: “A financial system that does not speak English", South European Society and Politics, vol. 14, no. 1, pp. 7-18.

Radaelli, C. (1998) 'Networks of expertise and policy change in Italy', South European Society and Politics, vol. 3, no. 2, pp. 1-22.

Radaelli, C. (2001) 'The Italian State and the euro: institutions, discourse, and policy regimes', in European States and the Euro: Europeanization, Variation and Convergence, ed K. Dyson, Oxford University Press, Oxford, pp. 212-237.

Saltari, E. \& Travaglini (2006) Le radici del declino economico dell'Italia. Occupazione e produttività in Italia nell'ultimo decennio, Utet, Torino. 
Schelke, W. (2011) 'A tale of two crises: the euro area in 2008/09 and in 2010', European Political Science, vol. 10, no. 3, September, pp. 375-383.

Tiffin, A. (2014) 'European Productivity, Innovation and Competitiveness: The Case of Italy', IMF Working Paper, WP/14/79.

Tombazos, S. (2011) 'Centrifugal tendencies in the Euro area', Journal of Contemporary European Studies, vol. 19, no. 1, March, pp. 33-46.

Toniolo, G. (2013) ‘An overview of Italy's economic growth', in The Oxford Handbook of the Italian Economy since Unification, ed G. Toniolo, Oxford University Press, Oxford, pp. 3-36.

Toniolo, G. \& Visco, V. (2004) (eds) Il declino economico dell'Italia. Cause e rimedi, Mondadori, Milano.

Trento, S. (2003) 'Stagnazione e frammentazione produttiva', Il Mulino, vol. 6, no. 410, pp. 1093-1102.

Trento, S. (2012), Il capitalismo italiano, Mulino, Bologna.

Turner, A. (2011) 'Debt and deleveraging: long term and short term challenges', Speech, Centre for Financial Studies: Frankfurt:

http://www.fsa.gov.uk/pages/Library/Communication/Speeches/2011/1121_at.shtml (accessed 20 April 2017).

Underhill, G. (2011) 'Paved with good intentions: global financial integration and the Eurozone's response', European Political Science, vol. 10, no. 3, pp. 366-374.

Verney, S. (2009) 'Flaky fringe? Southern Europe facing the financial crisis', Southern European Society and Politics, vol. 14, no. 1, pp. 1-6. 


\section{Notes}

\footnotetext{
${ }^{1}$ The following comparisons are drawn from the statistics provided in OECD (2017) for the various Euro-area countries. It should be noted that the Euro-area has expanded over time: 12 Member States entered the single currency on its launch date in 2002 (11 from 1999 plus Greece from 2001), followed by Slovenia (2007), Cyprus and Malta (2008), Slovakia (2009), Estonia (2011), Latvia (2014) and Lithuania (2015), numbering 19 today.

2 'Euro-Area Statistics' https://www.euro-area-statistics.org/competitiveness-indicators?cr=eur\&lg=en\&page=0 accessed 14 October 2017.

${ }^{3}$ World Bank Open Data, https://data. worldbank.org/indicator/BX.KLT.DINV.WD.GD.ZS?end=2016\&locations=IT-XC\&start=2007, accessed 14 October 2017.

${ }^{4}$ World Bank Open Data, https://data.worldbank.org/indicator/BM.KLT.DINV.WD.GD.ZS?end=2016\&locations=IT-XC\&start=2007, accessed 14 October 2017.

${ }^{5}$ World Bank Open Data, https://data.worldbank.org/indicator/NE.EXP.GNFS.ZS?end=2016\&locations=IT-

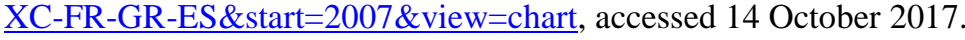

